\title{
A PRELIMINARY STUDY OF THE MANGROVE FOREST ON PULAU RAMBUT, JAKARTA BAY
}

\author{
by \\ KUSWATA KARTAWINATA $^{1)}$ and EKO B. WALUJO ${ }^{1)}$
}

Abstract

Pulau Rambut ( $\pm 56 \mathrm{ha}$ ) is one of the islands of the Pulau Seribu group. It is a coral island covered by disturbed forest and secondary growth at the center, and mangrove forest at its periphery. A study in a $290 \times 10$ m transect running south to north across the mangrove forest shows a distinct zonation as follows : the Scyphiphora hydrophyllacea - Lumnitzera racemosa community on coral flat with patchy shallow soils on the interior, the Rhizophora mucronata community on relatively deep soil overlaying coral formation, and the $R$. mucronata - $R$. stylosa community on periodically submerged coral flat. Profile diagrams established along the transect show structural changes also. The $R$. mucronata forest is the most developed community and appears to be the most prevalent. $R$. stylosa forms the pioneer species on this island.

\section{INTRODUCTION}

The mangrove forest of Indonesia covers a total area of about one million hectares (ANONYMOUS 1972), but so far only small portions of it have been studied ( BECKING et al. 1922; DE HAAN 1931; LUYTJES 1923; MEINDERSMA 1923, SoERIANEGARA 1968, 1971). The mangrove forest on the islands at the Jakarta Bay is also very little known and has been only described briefly (ANONYMOUS 1953, KAMERLING 1912). In view of the current development activities at and around the city of Jakarta that will undoubtedly bring about various negative effects on the aquatic biological communities in the Jakarta Bay, it is urgently necessary to initiate the baseline studies for monitoring the possible biological changes. The present study of the mangrove forest of Pulau Rambut constitutes a part of these baseline studies within the framework of the Man and Biosphere (MAB) project no. 5 : "Ecological effects of human activities on the value and resources of lakes, marshes, rivers, deltas, estuaries, and coastal zones". The present paper represents a preliminary report of this initial study.

\section{METHOD}

Pulau Rambut is one of the islands of the Pulau Seribu group, located on the Bay of Jakarta. It is a nature reserve, covering a total area of about

1) Herbarium Bogoriense, Lembaga Biologi Nasional, LIPI, Bogor 
25 hectares (ANONYMOUS 1957), but judging from the aerial photo the total land surface is estimated to be about 56 hectares. The island is surrounded by coral reefs and its vegetation consists of the depleted dryland tall forest dominated by Sterculia foetida and Chisocheton pentandrus, secondary growth dominated by climbers (a species of Cucurbitaceae, Wedelia biflora, and Merremia sp.), Scyphiphora hydrophyllacea - Lumnitzera racemosa scrub, mangrove forest, Ipomoea pes-caprae community and littoral sea-grass community dominated by Thalassia hemprichii and Enhalus acoroides (Fig. 1).

A transect of $290 \times 10 \mathrm{~m}$, running south to north across the mangrove forest on the northern part of the island, was established. All trees with diameter equaled to or greater than $10 \mathrm{~cm}$ were identified, counted and measured. Saplings were analysed with a series of continuous plots of $10 \times 2$ $\mathrm{m}$ each, and seedlings with subplots of $2 \times 1 \mathrm{~m}$ each arranged systematically at $10 \mathrm{~m}$ intervals. Composite soil samples were collected along the transect at every $10 \mathrm{~m}$. Profile diagrams along the transect were prepared.

\section{RESULTS AND DISCUSSION}

Along the transect only 10 tree species are recorded, i.e. Ceriops decandra, C. tagal, Lumnitzera racemosa, Pemphis acidula, Rhizophora mucronata, $R$. stylosa, Scyphiphora hydrophyllacea, Xylocarpus moluccensis, Excoecaria agallocha, and Thespesia populnea. The latter two species are not typical mangrove species, they usually occur on dryland beach. On the inland bordering the mangrove, Heritiera littoralis (not found in the transect) and Xylocarpus moluccensis are very common. During the reconnaissance study carried out earlier ( SOEMODIHARDJO et al. 1977), other mangrove species, i.e. Rhizophora apiculata, Bruguiera gymnorrhiza, Sonneratia alba, S. caseolaris, Avicennia alba, A. marina, and A. officinalis, are recorded also.

Along the transect, three communities may be recognized from the inland towards the sea : (1) Scyphiphora hydrophyllacea-Lumnitzera racemosa community, (2) Rhizophora mucronata community, and (3) Rhizophora mucronata-Rhizophora stylosa community, which occur on different habitats.

The Scyphiphora hydrophyllacea-Lumnitzera racemosa community is composed of only five species and only four species have diameters greater than $10 \mathrm{~cm}$ (Tables I and II). The total basal area of trees is only $2.3 \mathrm{~m}^{2} /$ ha and density is 151 trees/ha. The leading species, i.e. species with high basal area are Scyphiphora hydrophyllacea and Lumnitzera racemosa (Table I). No scrubs and herbs are recorded, but an epiphytic orchid, Aerides 


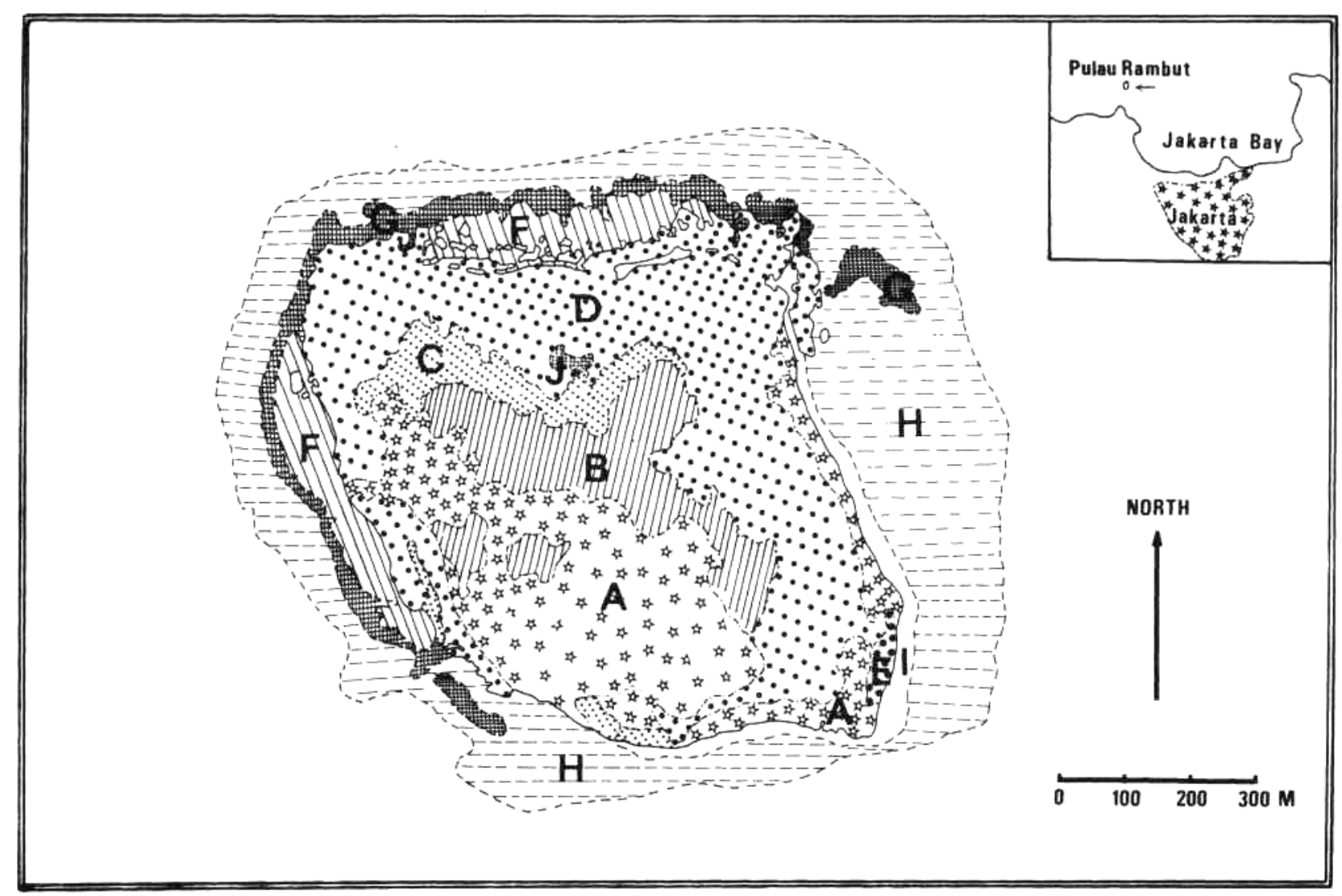

Figure 1. A map of Pulau Rambut showing its vegetation and surroundings: (A) dryland forest, (B) dryland secondary forest, (C) Scyphiphora-Pemphis community, (D) mangrove forest, (E) Ipomoea pes-caprae community, (F) ThalassiaEnhalus community, (G) lagoon, (H) coral reef, (I) sandy beach, and (J) cleared mangrove forest. The map was prepared from an aerial photograph that was made available through the courtesy of Mr. Jan Wind. 
KUSWATA K ARTAWINATA \& EKO B. WALUJO

Table I. The basal area (cm2) and the number of trees per hectare in the Scyphiphora hydrophyllacea-Lumnitzera racemosa community

\begin{tabular}{lcc}
\hline \multicolumn{1}{c}{ Species } & Basal area & Number of trees \\
\hline Scyphiphora hydrophyllacea & 8,328 & 50 \\
Lumnitzera racemosa & 7,862 & 25 \\
Pemphis acidula & 6,172 & 63 \\
Ceriops decandra & 157 & 13 \\
& & \\
\hline Total & 22,519 & 151 \\
\hline
\end{tabular}

Table II. The number of plants per hectare according to the diameter classes in the Scyphiphora hydrophyllacea-Lumnitzera racemosa community

\begin{tabular}{|c|c|c|c|c|c|c|c|c|}
\hline \multicolumn{9}{|c|}{ Diameter class $(\mathrm{cm})$} \\
\hline & $<2$ & $2-4.9$ & $5-7.9$ & $8-10.9$ & 11-13.9 & $14-16.9$ & $17-19.9$ & $>20$ \\
\hline \multicolumn{9}{|l|}{ Ceriops } \\
\hline decandra & 11,250 & 26,250 & 2,500 & 100 & & & & \\
\hline Ceriops tagal & & 8,125 & 625 & & & & & \\
\hline \multicolumn{9}{|l|}{ Lumnitzera } \\
\hline racemosa & 625 & 625 & & 13 & & & & 13 \\
\hline \multicolumn{9}{|l|}{ Pemphis } \\
\hline acidula & 625 & & 625 & 25 & 25 & 13 & & \\
\hline \multicolumn{9}{|l|}{ Xylocarpus } \\
\hline moluccensis & 625 & & 625 & & & & & \\
\hline \multicolumn{9}{|l|}{ Scyphiphora } \\
\hline hydrophyllacea & & & & 25 & 25 & & & \\
\hline
\end{tabular}

odorata, may be occasionally found. The community is open and low, where trees and saplings are scattered (Fig. 2a).

Most of the plants in this community are in the lower diameter classes and in the transect only Lumnitzera racemosa reaches diameter greater than $20 \mathrm{~cm}$ (Table II). Outside the transect some Scyphiphora hydrophyllacea trees with diameter of more than $20 \mathrm{~cm}$ are observed. It is evident from Table II that only Ceriops decandra has a good regeneration. This species 

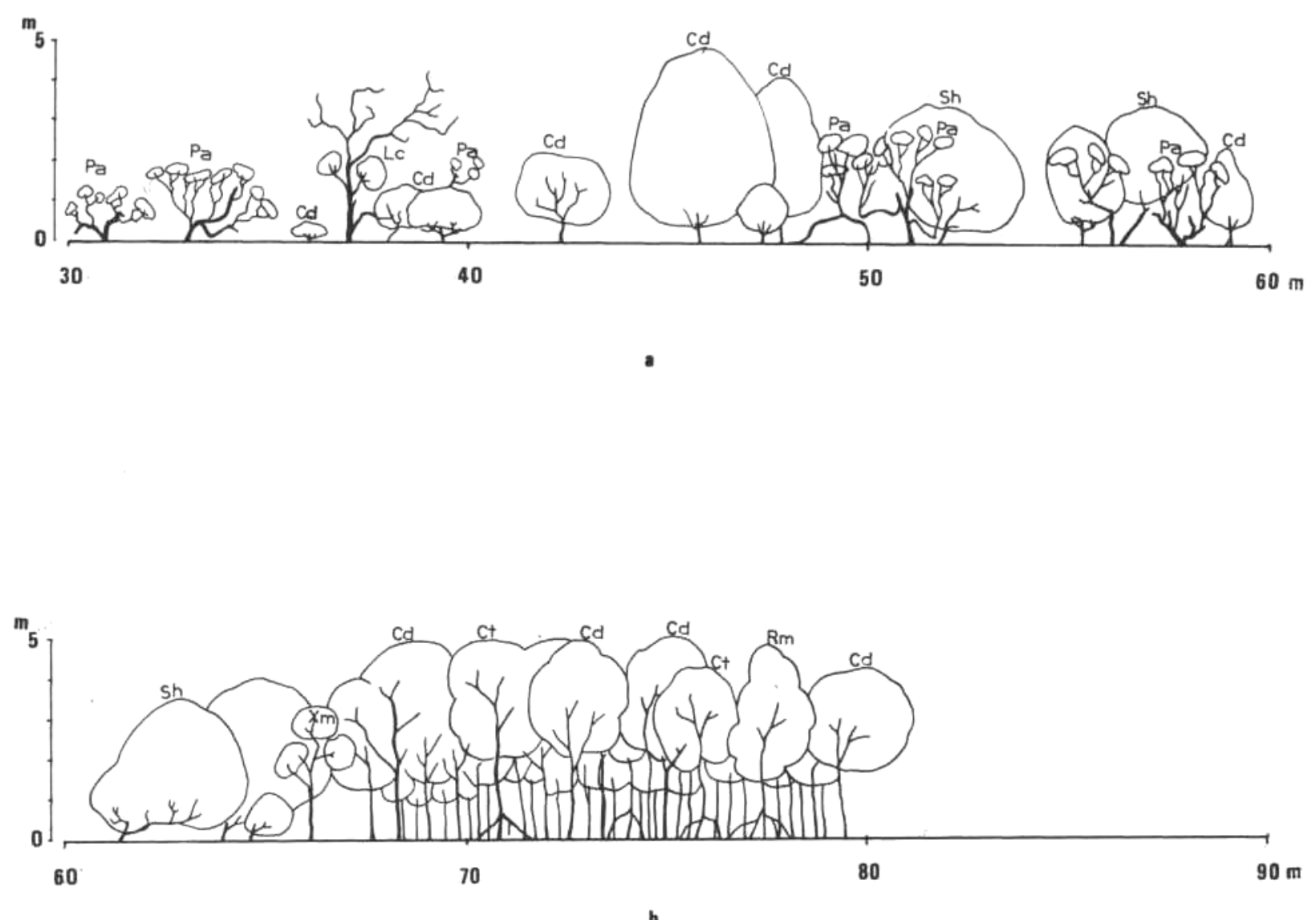

Figure 2. The profile diagram of the Scyphiphora-Pemphis community showing the typical portion (a) and the portion adjoining the clear-cut mangrove forest (b). The species represented in the profile are Ceriops decandra (Cd), C. tagal (Ct) Lumnitzera racemosa $(\mathrm{Lc})$, Pemphis acidula $(\mathrm{Pa})$, Rhizophora mucronata $(\mathrm{Rm})$. 
occurs abundantly on more muddy places close to the Rhizophora mucronata community, and it will perhaps become dominant in the community. The Scyphiphora hydrophyllacea-Lumnitzera racemosa community occurs on coral flatland with soils occurring as firm mud or on depressions not more than $20 \mathrm{~cm}$ deep on the inland part of the transect next to the coastal dryland forest. Reconnaissance around the island reveals that this community does not always occur on the inland part of the island between the coastal dryland forest and the Rhizophora mucronata community, but it may occur also near the beach or raised ground consisting of corals and mud. The soil under this community primarily consists of sand and a small amount of silt and clay and contains a little amount of organic matter, N, K, and Mg, but a high amount of $\mathrm{P}$ and Ca (Table IV).

Table III. Basal area (cm ) and the number of trees per hectare in the Rhizophora mucronata community

Species

Rhizophora mucronata

Ceriops decandra

Lumnitzera racemosa

Thespesia populnea

Total

63,434

The Rhizophora mucronata community extends for about $100 \mathrm{~m}$ along the transect. It is a pure community of Rhizophora mucronata, although Ceriops decandra, Lumnitzera racemosa, Excoecaria agallocha, and Thespesia populnea may also be occasionally present, but are insignificant and confined to the edges of the community (Figs. $3 a \mathrm{a}$ b). The total basal area of trees is $6.34 \mathrm{~m}^{2} /$ ha and density is 535 trees/ha, of which $6.32 \mathrm{~m} /$ ha and 434 trees/ha are occupied by $R$. mucronata (Table III). The number of saplings and seedlings amount to 2,634/ha and 16,333/ha, respectively. Figure 4 shows the population structure of Rhizophora mucronata in this forest. Most of the trees have diameters between 10 and $20 \mathrm{~cm}$, and the largest tree recorded is $24.7 \mathrm{~cm}$ in diameter with the height of about $12 \mathrm{~m}$. The forest is dense and the average canopy height is about $8 \mathrm{~m}$. The height of the trees in this community is very much lower than that in the well-developed mangrove forest, where $R$. mucronata may reach the height of $35-40 \mathrm{~m}$ (VAN STEENIS 1958). 

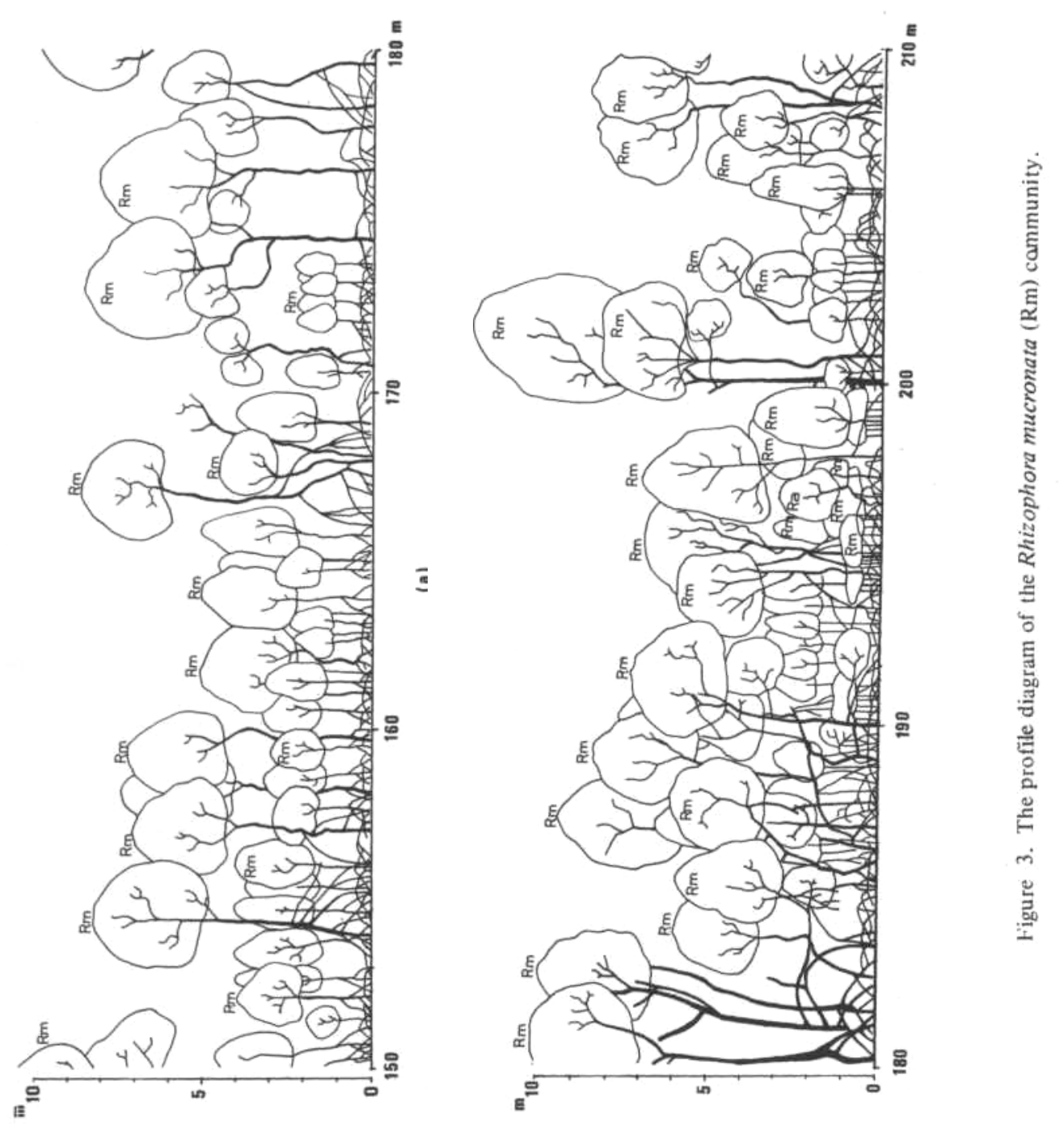


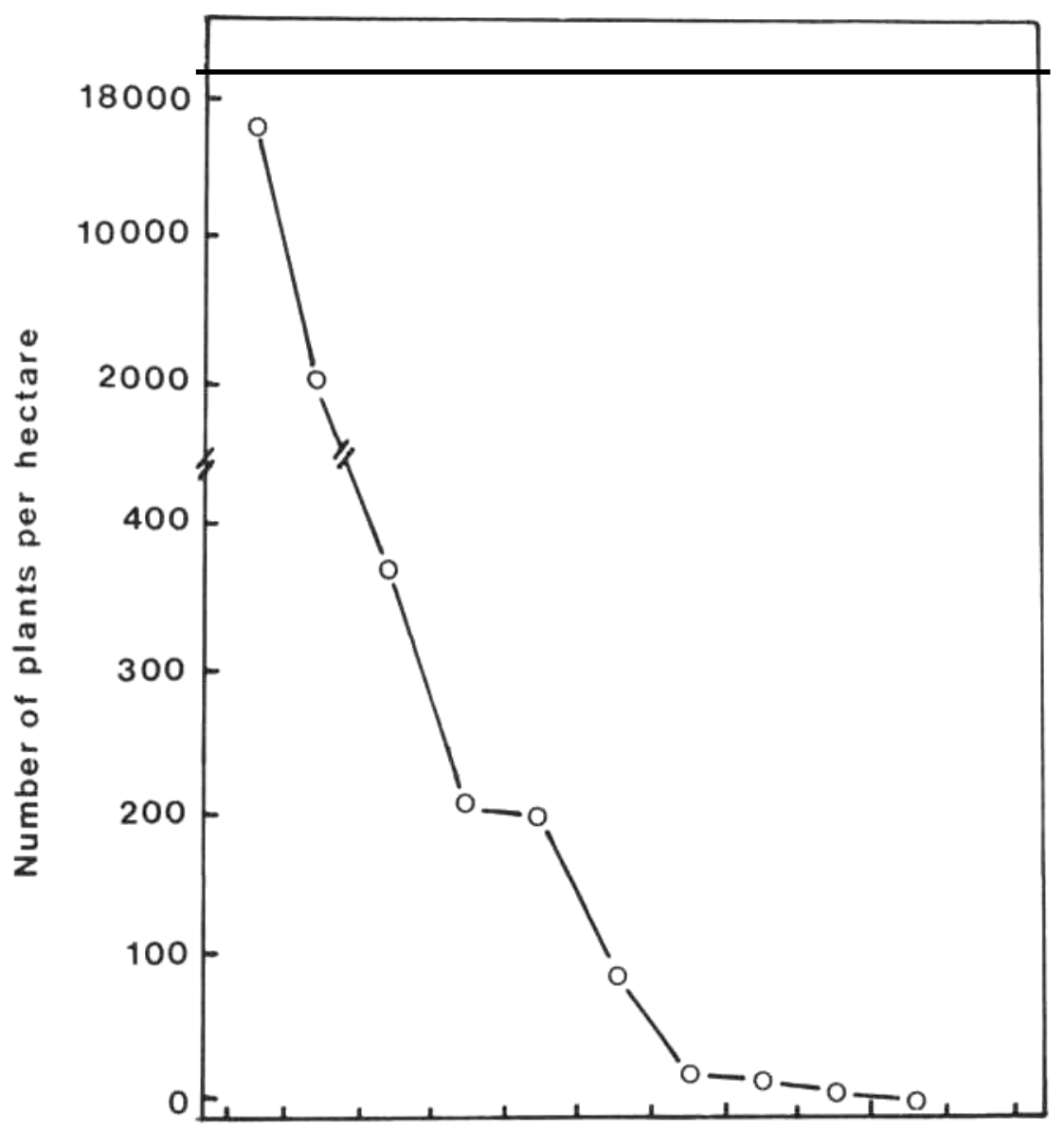

\section{$\begin{array}{llllllllllll}0 & 2 & 5 & 8 & 11 & 14 & 17 & 20 & 23 & 26 & 29 & 32\end{array}$ Diameter class midpoints}

Figure 4. Diameter class distribution of Rhizophora mucronata

This community occurs on dark brown soil overlying coral deposit and its depth ranges from 30 to $50 \mathrm{~cm}$. The soil is composed of equal fraction of clay and silt. The content of $\mathrm{K}, \mathrm{Ca}$, and $\mathrm{Mg}$ and organic matter is high (Table IV). The average amount of $\mathrm{P}$ to the depth of $50 \mathrm{~cm}$ is relatively low $(0.075 \%)$, but on the surface $(0-10 \mathrm{~cm})$ it is higher $(0.156 \%)$.

The $R$. mucronata community forms the most extensive mangrove forest on the island and always occupies the areas with deep soft soil and 
Table IV. Chemical and physical properties of the soil

\begin{tabular}{lccc}
\hline Soil properties & $\begin{array}{l}\text { Scyphiphora } \\
\text { Pemphis } \\
\text { community }\end{array}$ & $\begin{array}{l}\text { R. mucronata } \\
\text { community }\end{array}$ & $\begin{array}{l}\text { R. mucronata } \\
\text { R. stylosa } \\
\text { community }\end{array}$ \\
\hline Soil depth (cm) & $0-10$ & $0-50$ & $0-10$ \\
Texture (\%) & & & \\
Sand & 71.5 & 11.3 & 90.0 \\
Silt & 17.5 & 44.7 & 6.0 \\
Clay & 11.0 & 44.0 & 4.0 \\
$\mathrm{PH}$ & 7.6 & 6.7 & 7.6 \\
Organic matter (\%) & 7.8 & 62.1 & 2.0 \\
$\mathrm{Nutrients} \mathrm{( \% )}$ & & & \\
$\mathrm{N}$ & & 1.26 & 0.10 \\
$\mathrm{P}_{2} \mathrm{O}_{5}$ & 0.28 & 0.075 & 0.054 \\
$\mathrm{~K} \mathrm{O}^{5}$ & 0.282 & 0.283 & 0.040 \\
$\mathrm{CaO}$ & 0.082 & 11.357 & 49.723 \\
$\mathrm{MgO}$ & 47.962 & 1.704 & 0.874 \\
Exchangeable cations (m.e.) & 0.776 & & \\
$\mathrm{Ca}$ & & 68.8 & 27.1 \\
$\mathrm{Mg}$ & 33.9 & 69.5 & 7.5 \\
$\mathrm{~K}$ & 14.2 & 6.4 & 0.8 \\
$\mathrm{Na}$ & 1.3 & 149.3 & 21.4 \\
Total & 29.5 & 292.4 & 5.6 \\
$\mathrm{Adsorption}$ capacity & 79.1 & & \\
\hline
\end{tabular}

forms a more or less concentric band around the island (Fig. 1). In many places the inner boundaries do not lie side by side with the Scyphiphora hydrophyllacea-Lumnitzera racemosa community, but with the coastal dryland forest or the secondary growth. Similarly on the sea side it does not always border with the $R$. mucronata -- $R$. stylosa community, but with the dryland beach vegetation also. On the inner side of the transect, there is an opening which is completely devoid of plant cover and this apparently is the result of clear cutting. At present there is no regeneration or any sign of it being taken over by other species, such as Avicennia spp. which are pioneer species on such a habitat ( VAN STEENIS 1958).

The $R$. mucronata $-R$. stylosa community occurring on the transect is the pioneer community consisting of only saplings and seedlings. The average height of the plants is about $2 \mathrm{~m}$ (Fig. 5). The number of saplings of $R$. stylosa and $R$. mucronata is 500/ha each and that of the seedlings is $5,000 /$ ha and $3,333 /$ ha respectively. It occurs on coral flat, where the 


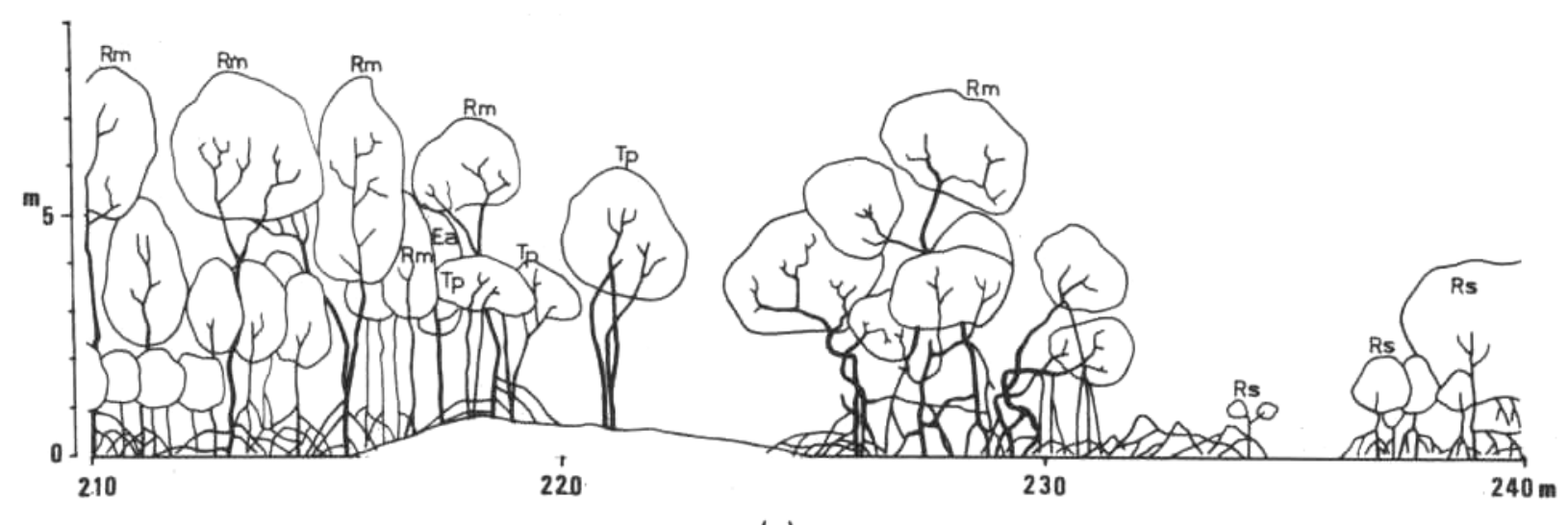

(a)

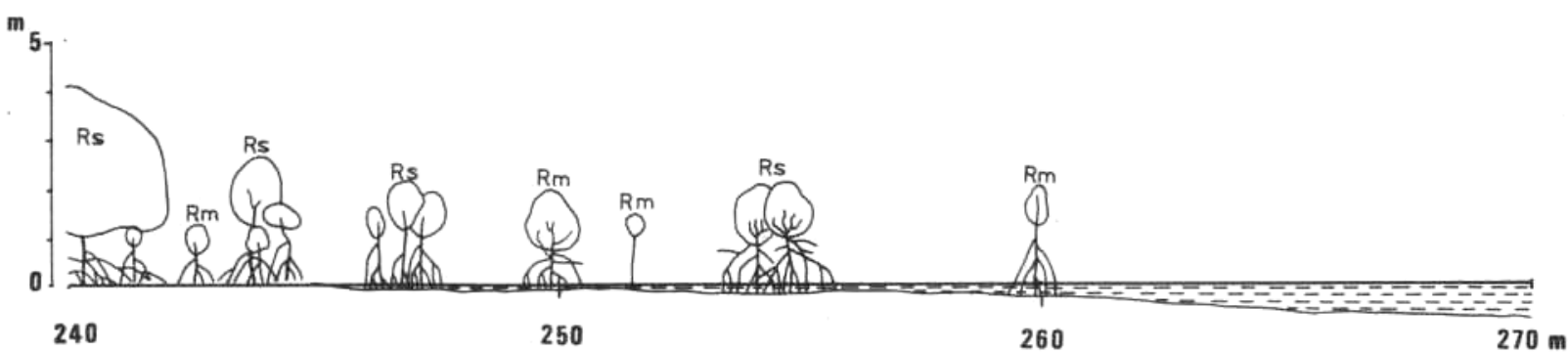

(b)

Figure 5. The profile diagram of the Rhizophora mucronata-Riiizophora stylosa community showing the portions adjoining the $R$. mucronata community (a) and on a small lagoon (b). The species repressented in the profile are Rhizophora mucronata (Rm),

R. stylosa (Rs), Thespesia populnea (Tp) and Excoecaria agallocha (Ea). 
substratum in which saplings and seedlings grow is $90 \%$ sand and is very low in the organic matter and nutrient contents. This community is affected by daily tidal movement. Adjacent to the transect and elsewhere on the island, there are older and better developed stands.

The zonation of the mangrove forest on this island is much simpler compared to that in the extensive mangrove forest occurring on estuaries elsewhere. This is apparently attributed to the relatively simple habitat conditions, where the tidal movement is the most important factor, whereas in the estuarine region the river flows from the inland, which affects salinity and brings about silt sedimentation, play an important role also. On this island there are only sand deposition on the beach and organic matter deposition, particularly on areas protected from daily tidal movements. The zonation is related also to the physical and chemical properties of the soil.

\section{REFERENCES}

ANONymous 1953. Een excursie naar Pulau Rambu (Middelburg) in de Baai van Djakarta. Trop. Natuur $33: 143$ - 144.

ANONYMOUS 1957. Widdlife and nature reserves in Indonesia. The Forest Service of Indonesia.

ANONYMOUS 1972. Forestry in Indonesia. Directorate General of Forestry, Department of Agriculture.

BECKING, J.H., L.G. DEN BERGER and H.W. MEINDERSMA 1922. Vloed of mangrove bosschen in Ned. Indie. Tectona $15: 561$ - 611.

DE HAAN, J.H. 1931. De Tjilatjapsche vloedbosschen. Tectona 24 : $39-76$.

KAMERLING. Z. 1912. De Rhizoohoren. Trop. Natuur 1 : 28 - 29.

LUYTJES, A. 1923. De vloedbosschen van Atjeh. Tectona $16: 575$ - 601.

Meindersma, H. W. 1923. Eenige bijzonderheden over mangrove-bosschen. Trop. Natuur 12 : 25 $31,39-46,70-77$.

SoemodihardJO, S., K Kartawinata and S. Prawiroatmodjo 1977. Kondisi hutan payau di Teluk Jakarta dan pulau-pulau sekitarnya. Oseanologi di Indonesia 7 : 1 - 23.

SOERIANEGARA, I. 1968. The causes of Bruguiera trees mortality in the mangrove forest near Tjilatjap, Central Java. Rimba Indonesia $13: 1$ - 11.

SOERIANEGARA, I. 1971. Characteristics and classification of mangrove soils of Java. Rimba Indonesia $15: 141$ - 150.

VAn SteEnIS, C.G.G.J. 1958. Ecology of mangrove. In Ding Hou : Rhizophoraceae. Flora Malesiana I, $5: 431-441$. 